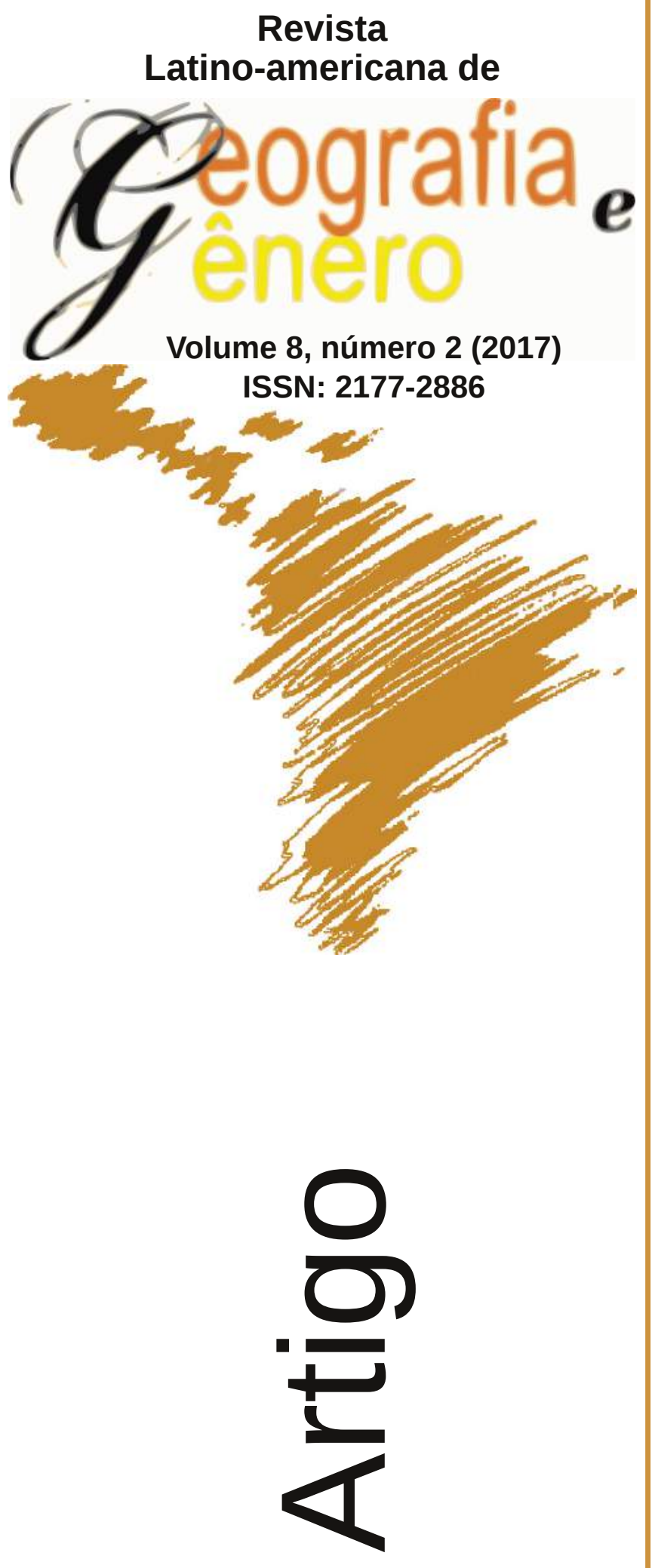

Juventude, Agricultura Familiar e Gênero: Um Olhar a Partir das Estudantes Matriculadas na UFFS (Campi Realeza/PR e Erechim/RS)

Juventud, Agricultura Familiar y Género: Uma Mirada a Partir de las Estudiantes Matriculadas em la UFFS (Campi Realeza/ PR y Erechim/RS)

Youth, Familiar Agriculture and Gender: A Look from the Point of View of Women Students

Enrolled in the UFFS (Realeza/PR and Erechim/RS Campi)

Márcio Freitas Eduardo

Universidade Federal da Fronteira Sul - Brasil marcioeduardo@uffs.edu.br

Daiane Carla Bordulis

Universidade Federal da Fronteira Sul - Brasil daiane.bordulis280@hotmail.com

Merce Paula Muller

Universidade Federal da Fronteira Sul - Brasil merce.muller@hotmail.com

Como citar este artigo:

EDUARDO, Márcio Freitas; BORDULIS, Daiane Carla; MULLER, Merce Paula. Juventude, Agricultura Familiar e Gênero: Um Olhar a Partir das Estudantes Matriculadas na UFFS (Campi Realeza - PR e Erechim - RS). Revista Latino Americana de Geografia e Gênero, v. 8, n. 2, p. 51-77, 2017. ISSN 2177-2886.

Disponível em:

http://www.revistas2.uepg.br/index.php/rlagg 


\title{
Juventude, Agricultura Familiar e Gênero: Um Olhar a Partir das Estudantes Matriculadas na UFFS (Campi Realeza/PR e Erechim/RS)
}

\author{
Juventud, Agricultura Familiar y Género: Uma Mirada a Partir de las \\ Estudiantes Matriculadas em la UFFS (Campi Realeza/ PR y Erechim/RS) \\ Youth, Familiar Agriculture and Gender: A Look from the Point of View of \\ Women Students Enrolled in the UFFS (Realeza/PR and Erechim/RS Campi)
}

\section{Resumo}

Através do arcabouço teórico da Geografia, o objetivo do presente artigo consiste em trazer à tona o debate do gênero em sua relação com a agricultura familiar, a juventude e a questão agrária no recorte de abrangência da UFFS, nos campi Erechim, RS e Realeza, PR. Os estudos intencionaram traçar um paralelo entre os problemas enfrentados na agricultura familiar regional em sua relação com as decisões que implicaram 1) na desterritorialização das jovens rurais e com 2) as perspectivas de permanência destas em seus espaços rurais de origem, no movimento de 3) acesso ao Ensino Público de nível Superior. Para tanto, com base em metodologias quanti-qualitativas, foram pesquisadas um total de 90 mulheres, jovens de origem rural.

Palavras-Chave: Gênero; Agricultura Familiar; Desterritorialização.

\section{Resumen}

A través del marco teórico de la Geografía, el objetivo del presente artículo consiste en mostrar el debate de género en relación con la agricultura familiar, la juventud y la cuestión agraria em el área de cobertura de la UFFS, en los campus Erechim/RS y Realeza/PR. Los estudios pretenden trazar un paralelo entre los problemas enfrentados en la agricultura familiar regional en su relación con las decisiones que implicaron 1) en la desterritorialización de las jóvenes rurales y con 2) las perspectivas de permanencia de éstas en sus espacios rurales de origen, en el movimiento de 3 ) acceso a la enseñanza pública de nivel superior. Para ello, en base a metodologías cuanyi-cualitativas, se investigó un total de 90 mujeres jóvenes de origen rural.

Palabras-Clave: Género; Agricultura Familiar; Desterritorialización.

\begin{abstract}
Through the theoretical framework of Geography, the aim of this article is to bring up the debate on gender in relation to familiar agriculture, youth and the agrarian question in the scope of the Federal University of the South Border (UFFS), Erechim/RS and Realeza/PR campuses. The research intended to draw a parallel among the different problems faced by regional familiar agriculture in its relation with decisions that implied: 1) the deterritorialization of rural young women; 2) the perspectives of permanence of these women in their original rural spaces; 3) their access to public higher education. For this, based on quantitative-qualitative methodologies, a total of 90 young women from the countryside were surveyed.
\end{abstract}

Keywords: Gender; Familiar Agriculture; Deterritorialization.

Márcio Freitas Eduardo, Daiane Carla Bordulis, Merce Paula Muller 


\section{Introdução}

Através do arcabouço teórico-metodológico da Geografia, o objetivo do presente artigo consiste em trazer à tona o debate do gênero em sua relação com a agricultura familiar, a juventude e a questão agrária no recorte de abrangência da UFFS (Universidade Federal da Fronteira Sul), mais especificamente, nos campi Erechim, RS e Realeza, PR.

O debate, aqui sistematizado, está respaldado por resultados de duas pesquisas, são elas: a) uma dissertação de mestrado em Geografia, defendida em 2016, intitulada, 'As Jovens Rurais e as Perspectivas de Permanência no Espaço Rural: um estudo de caso no campus Realeza da Universidade Federal da Fronteira Sul' (MULLER, 2016); e b) resultados de um trabalho de conclusão de curso em Geografia, produzido no ano de 2017, denominado 'Desterritorialização das Jovens Rurais: um olhar a partir das estudantes dos cursos de licenciatura da UFFS, Campus Erechim/RS' (BORDULIS, 2017).

Trata-se de um tema recente e ainda pouco explorado na Geografia brasileira. No âmbito do recorte de abrangência da UFFS, há enorme carência de pesquisas associadas, em que pese, ainda hoje, o agudo problema do êxodo rural na região (especialmente atrelado à desterritorialização das jovens rurais) e seu forte impacto frente aos desafios da sucessão da agricultura familiar.

Na mesorregião Sudoeste do Paraná (37 municípios), de acordo com o Censo Demográfico do IBGE, em 1991 a população rural correspondia a $52,8 \%$ do total, no entanto, a região, no decorrer dos anos, foi perdendo os moradores do campo, sendo que, em 2010, apenas 30,2\% das pessoas residiam no espaço rural (IBGE, 2010). Da mesma forma, segundo os Censos Demográficos do IBGE (1991 e 2010), a população residente na microrregião de Erechim, RS (30 municípios), no ano de 2010, era de 211.653 habitantes, dos quais 57.102 residiam no espaço rural. Importante destacar que, entre os anos de 1991 e 2010, a microrregião de Erechim perdeu em torno de 40\% de sua população rural. Por outro lado, sua população urbana aumentou os mesmos $40 \%$, concentrando-se, principalmente, no município de Erechim, cidade polo da microrregião. Os índices de migração do campo, envolvendo as populações jovens, são ainda mais acentuados nos referidos recortes, conforme abordaremos adiante.

Dessa forma, pelas 'lentes' do debate do gênero na Geografia, os estudos intencionaram traçar um paralelo entre os problemas enfrentados pela agricultura familiar regional em sua relação com as decisões que implicaram 1) na desterritorialização das jovens rurais e com 2) as perspectivas de permanência destas em seus espaços rurais de origem, no movimento de 3) acesso ao Ensino Público de nível Superior. Para tanto, com base em metodologias quanti-qualitativas, foram aplicados questionários e realizadas entrevistas com roteiro semiestruturados para um quantitativo de 69 jovens, em Realeza, PR, e para 21 jovens em Erechim, RS. Todas as pesquisadas tinham o mesmo perfil: jovens rurais que migraram para cidades e, atualmente, encontram-se matriculadas nos cursos de graduação nos campi Erechim (licenciaturas) e Realeza (licenciaturas e bacharelados) da UFFS. 
Juventude, Agricultura Familiar e Gênero: Um Olhar a Partir das Estudantes

Matriculadas na UFFS (Campi Realeza - PR e Erechim - RS)

\section{A UFFS Frente à Questão Agrária na 'Fronteira Sul': Aspectos Históricos e Perfil Institucional}

A Universidade Federal da Fronteira Sul (UFFS), criada pela Lei ${ }^{\circ} 12.029$, de 15 de setembro de 2009, iniciou suas atividades letivas no ano de 2010. Está inserida nos três estados da região Sul do Brasil, no recorte de abrangência da 'Mesorregião Grande Fronteira MERCOSUL' - classificação regional do Ministério da Integração Nacional. Portanto, traduz-se em uma instituição multicampi e interestadual situada, mais especificamente, no NorteNoroeste gaúcho (campi Cerro Largo, Passo Fundo e Erechim), no extremo Oeste catarinense (campus Chapecó) e no Sudoeste/Centro-sul paranaense (campi Realeza e Laranjeiras do Sul), conforme Mapa 1.

Mapa 01: Abrangência espacial da Universidade Federal da Fronteira Sul..

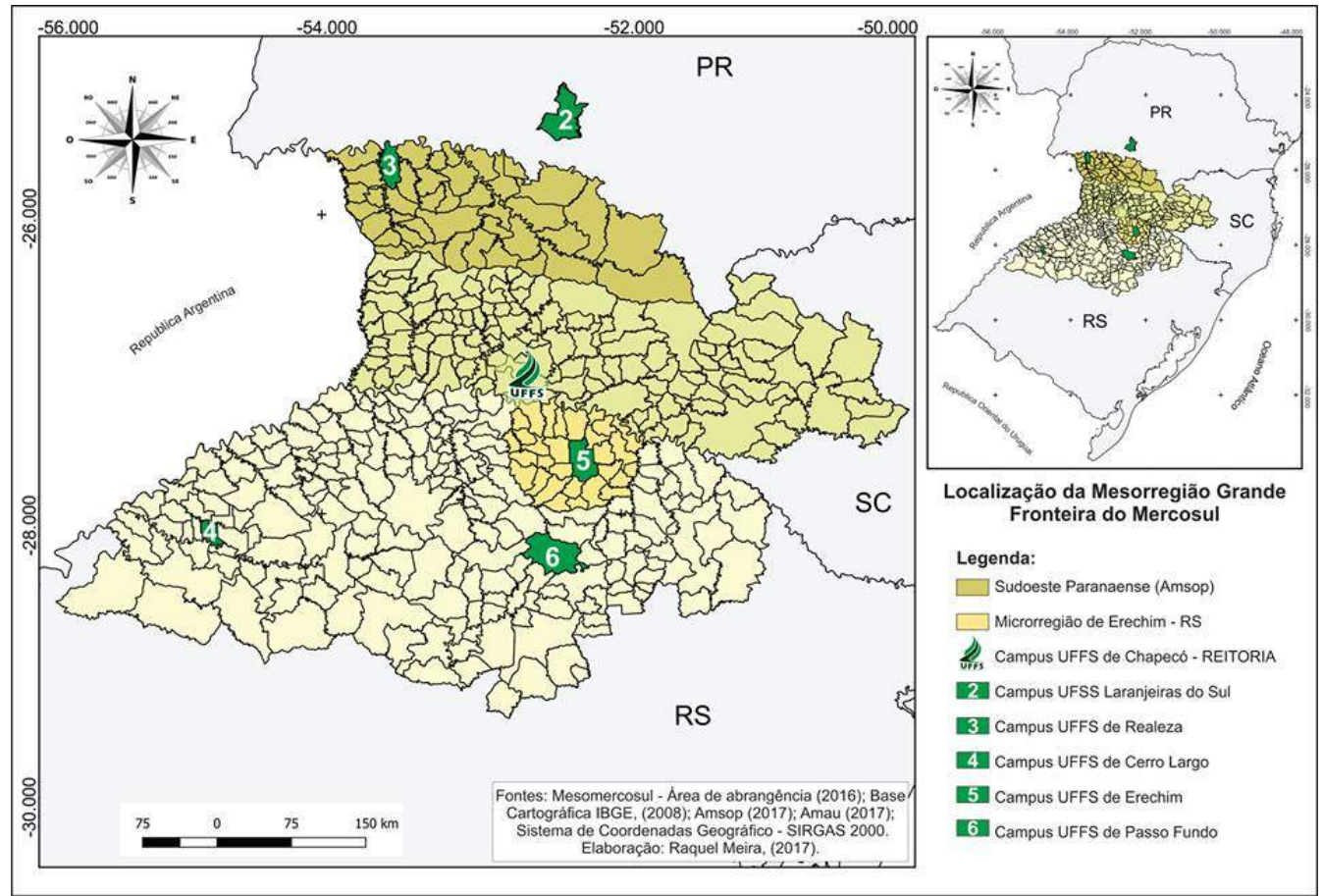

A UFFS é produto da mobilização e luta social popular organizada em âmbito do que se convencionou chamar 'Movimento Pró-universidade' (movimentos sociais e sindicais; ONGs; prefeituras e partidos políticos; movimentos estudantis secundaristas; entidades religiosas, etc.). Os grupos sociais que compuseram esse vasto e diversificado movimento alinharam-se pela demanda de criação de uma Universidade pública, gratuita, interiorana e que contribuísse para a formação crítica em nível superior dos filhos dos trabalhadores do campo e da cidade, arrancando-os das contingências históricas e espaciais que os alijaram do acesso à educação superior pública. Concomitantemente, o desejo por uma Universidade federal vinha ao encontro de outra demanda estratégica, a saber: construir uma instituição sólida que atuasse na produção de conhecimento (e não somente na sua reprodução) para enfrentar questões de desigualdades socioespaciais latentes da 'região', especialmente atreladas ao pleito da escola pública e ao campo, este último, no 
Matriculadas na UFFS (Campi Realeza - PR e Erechim - RS)

domínio da agricultura familiar (hegemônica no recorte referido) e dos processos de "monopolização do território pelo capital" (OLIVEIRA, 2001).

Em nossa leitura, dentre os temas prementes acerca da questão agrária regional que a UFFS visa enfrentar, com base em seu projeto Político Institucional (PPI), temos:

a) a necessidade de valorização da agricultura familiar como uma forma de produzir e organizar-se social e, espacialmente, com potencial de insurgência à territorialidade do agronegócio, na medida em que, historicamente, esses sujeitos produziram reproduzindo seus distintos modos de vida e não o modo do sistema produtor de mercadorias;

b) a demanda pela pesquisa para subsidiar as ações dos movimentos sociais, sindicais e entidades quanto à estruturação de políticas públicas que mitiguem o êxodo rural e urbano nos pequenos municípios, em especial, a evasão dos jovens do campo, e que permita apontar possibilidades para o desafio da sucessão na agricultura familiar e coloque em questão a temática do gênero;

c) a produção de conhecimentos, formas de manejo e tecnologias capazes de sinalizar para o desafio da transição agroecológica e da diversificação da matriz produtiva vigente, altamente concentrada na produção de três grãos (soja, milho e trigo) e em sistemas de integração contratuais com agroindústrias de grande porte como a BRFoods, Aurora e JBS;

d) $\mathrm{O}$ desenvolvimento de pesquisas que desvelem os traços fundamentais do modelo de produção e sua relação com a produção de bolsões de pobreza e vulnerabilidades no campo e na cidade;

e) $\mathrm{O}$ investimento em pesquisas no campo das alternativas energéticas; e

f) $\mathrm{O}$ aprofundamento do conhecimento e ações em âmbito da educação do campo e da formação inicial e continuada de professores, apoiado em pesquisa e extensão no recorte de abrangência da Universidade Federal da Fronteira Sul.

Dessa maneira, fica evidente a conotação popular intrínseca à UFFS. Os sistemas de cotas e ingressos diferenciados (para indígenas e haitianos, por exemplo) reforçam ainda mais essa premissa. Contudo, o que era ser popular em 2010, uma instituição muito concatenada aos pleitos da agricultura familiar e da escola pública, ampliou-se em complexidade para contemplar o popular do indígena, do afrodescendente, do imigrante e das distintas orientações sexuais e de gênero.

Hoje, a UFFS conta com 40 cursos de graduação (nas mais variadas áreas: educação, saúde, exatas, tecnológicas, etc.), diversos cursos de pós-graduação stricto sensu e já ultrapassou o contingente de 8.000 alunos em seus sete anos de história. No campus Erechim, há, atualmente, nove cursos de graduação, são eles: Agronomia, Arquitetura e Engenharia Ambiental, englobando os bacharelados; e, Ciências Sociais, Educação do Campo, Filosofia, Geografia, História e Pedagogia, no rol das licenciaturas. Conta, ainda com outros três cursos de pós-graduação stricto sensu. No campus Realeza, há sete cursos de graduação, a saber: Ciências Naturais, Letras, Física, Química e Ciências Biológicas, no âmbito das licenciaturas; Nutrição e Medicina Veterinária, ao que tange os bacharelados.

Desde o início de suas atividades, a UFFS tem sido destino pretendido por um número expressivo de jovens da 'região', os quais, em grande medida, 
Matriculadas na UFFS (Campi Realeza - PR e Erechim - RS)

apresentam fortes ligações com o campo, seja pelo exercício da prática profissional (agricultores; ex-agricultores) ou pela identidade intergeracional (filhos de agricultores). Em nossas observações e pesquisas identificamos que a procura pelo ensino superior pelos jovens está atrelada às dificuldades de reprodução da agricultura familiar na 'região' e, por parte das jovens rurais, soma-se ainda a problemática das desigualdades e sistemas de opressão intrínsecos às relações de gênero no campo. Assim, cursar uma graduação tem sido uma estratégia utilizada por esses sujeitos, no sentido de galgarem construir alternativas a esse panorama de crise e de dificuldades inerentes à questão agrária acirrada no recorte espacial da 'Fronteira Sul'. Como corolário, a profissionalização urbana em nível superior dificilmente viabiliza a continuidade ou mesmo o retorno desses jovens ao campo. Em nossas pesquisas e reflexões, evidenciamos a necessidade de mudanças também nas políticas agrárias/agrícolas para a agricultura familiar, especialmente no sentido apontado pelo PPI da UFFS, de mudanças na matriz produtiva regional, as quais apontem para formas mais inclusivas e equilibradas ecologicamente. Trata-se, sem dúvidas, de questões muito abrangentes e de elevada relevância para pesquisas futuras.

Com efeito, trataremos, a partir de ora, de um tema imbricado a essa problemática maior: abordaremos os debates do gênero e da juventude rural em suas interfaces com a Geografia para subsidiar, posteriormente, as discussões acerca dos resultados obtidos com as pesquisas já referidas.

\section{Geografia, Gênero e Juventude Rural: Aspectos Teóricos Introdutórios da Problemática}

Ao nos propormos estudar as jovens rurais estudantes da UFFS, o fazemos em decorrência, também, da expectativa, construída pelos movimentos que deram origem a referida Universidade, de que as ações destas jovens tenderiam a alterar de forma qualitativa a organização local, em especial, da agricultura familiar, nas quais estão inseridas e, também, de que a Universidade seria importante para a construção de projetos de vida e de permanência.

Segundo Weisheimer (2005), há diversos conceitos de juventude, os quais a definem como ciclo de vida, geração, faixa etária, cultura ou modo de vida e representação social. Fica nítido, doravante, que os estudos e pesquisas realizados sobre os jovens/condição juvenil vêm aumentando nos últimos anos. Conforme Weisheimer (2005, p. 3), "as demandas da juventude, seja urbana seja rural, passaram a ser reconhecidas como importantes e legítimas e a ser incorporadas pelo Estado e, mesmo, pelos movimentos sociais [...]", pois os jovens passaram a ser considerados como estruturantes da dinâmica social. $\mathrm{O}$ conceito de juventude, assim compreendemos, é preciso ser flexível o suficiente para dialogar com as transformações e a dinamicidade próprias da condição juvenil. Os jovens, com base em suas territorialidades cotidianas (integração a distintos grupos sociais; diferentes contextos espaciais em que estão inseridos), estabelecem relações que frequentemente reconfiguram suas próprias identidades e leituras de mundo. Um conceito excessivamente rígido sobre juventude acabaria por simplificar, demasiadamente, realidades em movimento marcadas pela elevada complexidade. 
Ao que se refere ao campo e a agricultura familiar, é de suma importância que sejam intensificados pesquisas a respeito para que propiciem avanços mais significativos no conhecimento sobre as condições juvenis e as questões de gênero inerentes. Tais pesquisas poderiam indicar caminhos possíveis para intervenções via políticas públicas e, ainda, subsidiar os debates junto aos movimentos de organização social de base, pois estamos tratando de questões estruturantes à continuidade da agricultura familiar. Obviamente, quando a juventude não projeta o campo como lócus, território de vida, não há horizontes para a reprodução das territorialidades e formas de produzir associadas à chamada agricultura familiar.

Compreender a juventude numa perspectiva da diversidade socioespacial (do ponto de vista dos problemas e, igualmente, das experiências exitosas) é uma tarefa da agenda atual a qual se configura como uma premissa multidisciplinar, porém, marcadamente geográfica. Pois, como afirma Moreira (2011), o exercício da sociabilidade é, sobretudo, uma prática que é gestada e acontece nos interstícios das condições espaciais de existência dos sujeitos. Considerando que o campo e os valores atrelados à agricultura familiar são elementos ativamente importantes na constituição da cultura e da territorialidade dos jovens no Sul do Brasil, a apreensão geográfica soma-se ao trabalho e ao conjunto de preocupações abordadas por pesquisadores de outras áreas.

$\mathrm{Na}$ Geografia brasileira ainda são poucos os estudos voltados para temática da juventude rural e do gênero. Aos poucos, o interesse pelo tema vem aumentando entre os geógrafos. Como afirma Pires (2013), há tentativas de alguns pesquisadores geógrafos do tema em constituir uma área sólida de investigação em torno da juventude, de forma a incorporar a juventude rural. Com relação aos estudos referentes às questões de gênero, como pondera André (1990), é a partir de 1980 que alguns geógrafos começaram a alertar para introdução de gênero nas pesquisas, procurando evidenciar que a organização social e territorial engloba diferenças entre as mulheres e os homens.

Definimos gênero, com base em Scott (1989), como uma maneira de referirse à organização social da relação entre os sexos. Além disso, para Silva e Schneider (2010), o conceito de gênero questiona o que é dado como natural e biológico, demonstrando que, na sociedade, o papel da mulher pode ser alterado com benefícios para o todo.

De acordo com Silva (2003), na Geografia norte-americana e europeia, a vitalidade nos debates sobre as relações de gênero e espaço é maior, "[...] as quais têm contribuído significativamente para legitimar o tema enquanto problema científico, fundamentando seus estudos na existência do feminismo enquanto um parâmetro simbólico". Os estudos realizados pelas geógrafas:

[...] trazem a identidade feminina como sendo um agente importante na compreensão do espaço e também assumem um compromisso de abordar questões de relações de poder e hierarquia que transformam em assimétricos o desenvolvimento sócio-espacial nas relações de gênero (SILVA, 2003, p. 35).

Márcio Freitas Eduardo, Daiane Carla Bordulis, Merce Paula Muller 
Há, ainda, que se considerar que a “[...] história dos espaços também envolve a força, tanto física, como simbólica e, portanto, a geografia feminista quer compreender como o sujeito feminino é construído dentro das estruturas de dominação sócio-espaciais" (SILVA, 2003, p. 37). Com esse intuito "[...] a abordagem feminista argumenta que o território possui suas diferenciações internas e que no território conquistado pela força masculina também existe o espaço do outro - o feminino" (SILVA, 2003, p. 39). De acordo com Silva (2003, p. 6),

[...] o ponto central dos estudos geográficos através desta perspectiva é o argumento de que mulheres e homens tem se posicionado diferentemente no mundo e, sendo assim, suas relações com os lugares são diferentes também. Além disso, essas diferenças são resultados de um conjunto de elementos reveladores da opressão das mulheres pelos homens em diferentes lugares e em diferentes tempos. A visão da construção social da feminilidade e da masculinidade posicionou os estudos geográficos para além da busca pela objetividade científica e, assim, o conjunto de relações sócioespaciais, os significados dos lugares e a explanação sobre eles, são múltiplos, mutáveis e multidimensionais.

Do ponto de vista de nosso recorte espacial de investigação, a 'região' de abrangência da UFFS, a condição das jovens rurais é produto de aspectos históricos, identitário-cultural e de ordem econômico-produtivo. O mencionado recorte apresenta pouca diferença na sua formação econômica. Seu processo histórico, na primeira metade do século XX, foi marcado por projetos de colonização (estatal e particular) envolvendo, sobretudo, descendentes de italianos, alemães e poloneses, destacando-se, ainda, a formação de pequenos estabelecimentos de agricultura familiar com produção (em um primeiro momento) de alimentos básicos como o feijão, milho, trigo, mandioca, produção de leite e a criação de suínos, evoluindo, atualmente, para a produção agroindustrial integrada (aves, suínos e leite) e para a especialização produtiva de grãos (principalmente soja, milho e trigo). Essas transformações econômico-produtivas ocorreram (e estão em curso) nos estabelecimentos paralelamente à permanência, em intensidade variada, da produção para o autossustento, essencialmente realizada pelo trabalho feminino: tradição e modernidade vis-à-vis.

Do ponto de vista cultural, nesses estabelecimentos de agricultura familiar, geralmente são os homens considerados 'chefes das propriedades' e, as mulheres, responsáveis pelas atividades domésticas, cuidados com os animais, horta e outras atividades desenvolvidas nas unidades de produção, persistindo uma ideia de que o trabalho desenvolvido pelas mulheres trata-se de 'ajuda'. A 'ajuda' na reprodução do ciclo de vida familiar é encarada como condição para o 'trabalho produtivo', especialmente o masculino, vinculado à sua faceta monetarizada, portanto, 'visível' e 'economicamente importante'.

A compreensão do trabalho feminino na unidade de produção como uma 
Matriculadas na UFFS (Campi Realeza - PR e Erechim - RS)

'ajuda' é especialmente marcante nos contextos da agricultura familiar de origem étnica 'euro-brasileira'. E consiste em uma das questões de gênero que mais se apresenta na agricultura familiar, em momentos mostrando sua persistência e em outros mostrando suas transformações.

Para fazer frente a esse e outros sistemas de opressão de gênero, na década de 1980, junto a um processo de rearticulação da classe de trabalhadores na forma de movimentos sociais no campo, houve mobilizações que resultaram na criação da maioria dos movimentos de mulheres trabalhadoras rurais, num processo de construção da emancipação política feminina em um cenário de luta pela terra e por melhores condições de trabalho no campo. No período atual, as mulheres rurais vêm demonstrando seu empoderamento, tanto em questões de inserção e organização política, quanto em seus cotidianos de trabalho nos contextos das unidades familiares de produção. Manifestação disso encontramos no escopo de políticas públicas mais recentes as quais, explicito (inclusão produtiva das mulheres, por exemplo) ou tacitamente (a exemplo dos "mercados institucionais"), interveem no domínio das questões de gênero.

Políticas públicas como o Programa de Aquisição de Alimentos (PAA) e o Programa Nacional de Alimentação Escolar (PNAE), por exemplo, contribuem significativamente para o fortalecimento da agricultura familiar. São responsáveis, também, por trazer à superfície a questão do gênero e mesmo rearticular as dinâmicas de produção no interior das unidades. A produção de alimentos básicos, anteriormente destinados exclusivamente para o consumo da família (hortaliças, legumes etc.), e produtos agroindustrializados artesanalmente como geleias, bolachas e pães, são comercializados através destes programas, gerando renda e incluindo produtivamente os distintos membros das famílias rurais. Atividades produtivas que anteriormente eram realizadas exclusivamente pelas mulheres nos estabelecimentos de agricultura familiar, passam a envolver toda família, quer seja na produção ou mesmo na comercialização.

No entanto, o empoderamento das mulheres no espaço rural e as melhorias no âmbito das políticas públicas em favor delas, ainda não são suficientes para a permanência das jovens rurais no campo.

As condições em que são desenvolvidas hegemonicamente as atividades agrícolas nas unidades produtivas familiares (na produção convencional de grãos, por exemplo), a vulnerabilidade da agricultura em relação às condições meteorológicas, ao mercado, as questões de organização do trabalho e de distribuição da renda acabam não sendo atrativas, principalmente para as jovens rurais, fazendo com que problemas como o envelhecimento e a masculinização da população no espaço rural se tornem latentes. Há, ainda, que considerar que os:

[...] elevados índices migratórios do meio rural em direção às cidades, com a predominância de jovens e, entre eles, de mulheres, implicando no envelhecimento e masculinização da população rural; e, por outro lado, do aumento de problemas ligados à sucessão geracional nos estabelecimentos familiares, seja pela dificuldade de

Márcio Freitas Eduardo, Daiane Carla Bordulis, Merce Paula Muller 
encontrar sucessor entre os filhos dos proprietários, seja pelos conflitos entre os herdeiros legais em torno da partilha do patrimônio familiar (BRUMER e ANJOS, 2008, p. 7).

Aguiar e Stropasolas (2010, p. 165) enfatizam que "as moças, de um modo geral vivem insatisfeitas com sua condição. A divisão do trabalho na unidade familiar lhe destina o espaço da casa, a esfera doméstica”. Pois, as atividades desenvolvidas pelas moças não são considerados como trabalho produtivo e não possibilita o acesso a renda. Portanto, "tal condição serve de estímulo para que as moças logo pensem em se empregar na cidade, a fim de garantir, através do salário, uma renda que lhe seja própria. Elas não veem perspectiva em ficar na propriedade" (AGUIAR e STROPASOLAS, 2010, p. 165-166):

Essa atitude das jovens do meio rural diante de seus projetos de vida evidencia uma vontade de romper com o papel feminino encarnado pelas mulheres das gerações que as precederam, ruptura que costuma receber o apoio incondicional de suas mães. Isto é, as mulheres na posição social de mães das jovens que migraram para outras localidades com a aspiração de construir um estilo de vida urbano, ao serem questionadas sobre a possibilidade de terem seguido o mesmo caminho das filhas, enunciaram impedimentos sustentados em questões culturais (WAGNER, MARQUES, MENASCHE, 2007, p. 54-55).

Além disso, segundo Pires (2013, p. 87), "mesmo considerando a diversidade de situações e posturas dos jovens em relação ao trabalho, o mundo do trabalho aparece para eles como uma mediação efetiva e simbólica na experimentação da condição juvenil". Para autora, esses jovens trabalham para ter dinheiro, permitindo dessa forma, o acesso ao consumo, a produtos que lhes tragam bem estar e que possibilite construir uma imagem de pertencimento ou distinção junto a determinados grupos sociais.

Da mesma forma, a postura dos jovens rurais em relação ao acesso à Universidade pública inscreve-se na procura pela construção de uma condição que os faça avançar, de quadros de vulnerabilidade econômica, de opressão de gênero e de dependência adultocêntrica, para formas de ser, pensar e trabalhar com maior autonomia e segurança econômico-profissional:

[...] a saída da jovem da casa da família e da comunidade rural possibilita, geralmente, sua ascensão social, o que, na maioria das vezes, acontece a partir do investimento em educação, da inserção no mercado de trabalho urbano e/ou do casamento com homens provenientes do meio urbano. O estilo de vida possível de ser conquistado nas cidades garante à mulher maior autonomia e participação (WAGNER, MARQUES e MENASCHE, 2007, p. 54).

Em nossas pesquisas, constatamos que são multifatoriais as questões de 
Matriculadas na UFFS (Campi Realeza - PR e Erechim - RS)

gênero envolvendo as jovens rurais. Há relações de poder assimétricas internas às unidades de produção que as relegam a uma posição de subalternidade frente aos pais (pai e mãe) e até aos irmãos, influenciando-as a forjar suas territorialidades nos limites do padrão assumido pelas mulheres adultas, isto é, nos interstícios do trabalho reprodutivo doméstico. As mães, inclusive, têm papel ativo na afirmação do patriarcado. Do ponto de vista das jovens, estas tendem a permanecer subsumidas há um duplo sistema de opressão: o de gênero e o adultocêntrico.

Em termos econômicos, as transformações produtivas deflagradas pela 'modernização' da agricultura, reafirmou tecnicamente a hegemonia masculina. São o pai e os filhos homens, geralmente, quem desenvolve as atividades produtivas de interesse comercial. Igualmente, decisões econômicas importantes, como o planejamento da produção; o estabelecimento de contratos com as agroindústrias e os bancos; e a própria gestão dos recursos financeiros da família, são atribuições, em grande medida, dos homens adultos. O modelo de desenvolvimento do agronegócio tende a 'ativar a territorialidade' (DEMATTEIS, 2008) adulta e masculina em detrimento da territorialidade feminina, especialmente a jovem.

Nessa esteira, as jovens rurais se veem circunscritas por relações sociais e de poder reprodutoras da 'territorialidade passiva' (DEMATTEIS, 2008). Seja frente à família ou ao agronegócio, reproduzem projetos pré-definidos por estruturas de controle estranhas ao seu empoderamento. É no centro dessas contradições vivenciadas pelas jovens rurais que se coloca o acesso ao ensino superior. Profissionalizar-se em nível superior, contudo, pode representar tanto a possibilidade de retorno e permanência das jovens, quanto a sua desterritorialização do campo.

\section{Jovens Rurais em Realeza/PR: Evasão e Perspectivas de Permanência nos Espaços Rurais}

No caso das jovens rurais do Campus Realeza da UFFS, optamos por compreender os elementos que fomentaram as decisões para a permanência ou para a saída de seus espaços rurais. Assim, as jovens participantes da pesquisa se caracterizaram por: $66 \%$ estar na faixa etária compreendida de 19 a 22 anos; $84 \%$ solteiras; e, a maioria delas residia nos municípios da região Sudoeste do Paraná.

São filhas de pequenos agricultores familiares, dos quais $91 \%$ possuíam 'propriedades' próprias, sendo que $41 \%$ das unidades produtivas têm menos de 10 hectares e $32 \%$ com estabelecimentos agropecuários entre 10 a 20 hectares. Nas unidades de produção familiar, constatou-se que a principal atividade econômica era a produção leiteira, envolvendo um quantitativo total de $33 \%$ das famílias e, em segundo lugar, comparecia a produção de grãos, representando $25 \%$.

Inicialmente, em relação à permanência no campo, duas questões foram centrais: 1) se as jovens pretendiam permanecer no campo e 2) o que era preciso para tal. A partir das respostas definimos três grupos: as que pretendiam permanecer, as que intencionavam migrar e as que ainda não haviam se decidido no momento desta etapa da pesquisa. 
Matriculadas na UFFS (Campi Realeza - PR e Erechim - RS)

Assim, definimos três grupos, sendo o Grupo I (36\% ou 25 jovens que responderam que ainda não decidiram); Grupo II (47\% ou 32 jovens que responderam não ter interesse) e o Grupo III (17\% 12 jovens que responderam que sim, mas com mudanças).

Após a tabulação e análises dos dados, a partir destes três grupos, retornamos ao grupo constituído pelas jovens que, inicialmente, intencionavam ficar no campo, mas com mudanças, para, dessa forma, conseguir compreender as perspectivas de permanência. Neste momento verificamos que uma delas havia mudado de opinião:

[...] eu não consigo ver oportunidade no campo, hoje em dia pra você consegui crescer e chegar num status que a gente sempre tenta buscar. [...] Se eu não conseguir um trabalho na cidade ou coisa assim, eu não digo que eu não vou permanecer no espaço rural, eu vou continuar lá, eu vou dar sequência o que a minha mãe tá fazendo, tipo assim, vamos tocar as coisas, mas não vejo um motivo para ficar, meu maior motivo seria se eu não conseguir alguma coisa na cidade, talvez um período curto, mas minha intenção não é ficar lá (JOVEM A, 2015).

Essa jovem demonstra não possuir interesse em permanecer no espaço rural, sendo a perspectiva econômica uma motivação para a migração, mas não é exclusiva, pois a "[...] maior integração aos valores da sociedade urbanoindustrial estimulam a formulação de projetos individuais voltados para o objetivo de 'melhorar de vida"” (CARNEIRO, 1999, p. 104). O desenvolvimento das atividades agrícolas não consegue dar uma perspectiva segura na questão econômica, pelas questões meteorológicas, devido às oscilações de preço no mercado e pela a falta de políticas públicas de incentivo aos agricultores, especialmente.

Segundo Castro (2005), a juventude rural é marcada pelo dilema de 'ficar ou sair'. Estas 'opções' são permeadas por diversas questões, das quais os jovens têm sobre si cobranças como a sobrevivência da família, à reprodução de modos de vida e de heranças identitário-culturais, etc. A mudança e a permanência têm, ainda, uma relação direta, embora não exclusiva, com a questão econômica e com a importância do jovem como mão de obra ou como consumidor, na família rural.

Como vimos nos depoimentos e nos trabalhos de diversos autores como o de Castro (2005), são inúmeras as questões relacionadas à decisão dos jovens em relação à permanência no espaço rural, sendo que a importância deste para o trabalho rural é um elemento central para a família, o qual pode ou não ser considerado pelas jovens em suas decisões por migrar. Por isso, a decisão, independente de qual seja, representa possibilidades de mudanças, rupturas e de reestruturações da própria concepção de juventude rural e do estereótipo de questão geracional (centrada na faixa etária) que remete ao jovem do campo uma caricatura de docilidade, especialmente ao nos referirmos às mulheres. Concepção esta agregada à ideia de mulher trabalhadora e submissa.

A decisão de morar no campo não se restringe a dimensão econômica, pois a vida no campo está relacionada às condições de acesso e de permanência, 
englobando, também, as dimensões políticas e culturais, as quais envolvem não somente a pessoa interessada, mas ao grupo social em qual está inserida e aos desdobramentos de tais decisões. Trata-se de uma lógica espacial, inclusive, onde este é causa e consequências de relações endógenas e exógenas nas quais está inserida a organização da agricultura familiar, por exemplo.

Na verdade, lá em casa é muito pequeno, entende [...]. Tudo assim é muito pequeno, não tem muita coisa, não vejo assim perspectiva. Assim, para residir, mas não para trabalhar na agricultura lá [...]. O que faria? Eu permaneceria lá? Não sei. Ou eu trabalharia com licenciatura no meu curso? Ou ficaria numa escola mais próxima da cidade, no sentido de eu trabalhar na agricultura? Eu não. Só residir. Talvez, isso (JOVEM C, 2015).

Dentre as jovens que destacaram a intenção de trabalhar na área de sua graduação, há manifestações de possíveis dificuldades de ingresso no mercado de trabalho. Assim, a permanência na unidade produtiva até que consiga um trabalho não agrícola é considerada como opção. Mas, é evidente que o afastamento do espaço rural para estudar, principalmente para aquelas jovens que construíram um laço urbano mais forte durante a graduação, se constitui elemento que dificulta sua reterritorialização ao espaço rural, principalmente quando neste a falta de infraestruturas de lazer predominam, especialmente às mulheres, as quais ficam restritas aos espaços de sociabilidade do convívio familiar.

No Sudoeste paranaense, as unidades de produção familiar, conforme estudado por Santos (2010), passaram por um processo intenso de modernização, mesmo quando se refere à produção de leite, diminuindo a necessidade de mão de obra no campo, especialmente a das mulheres. Este fato proporciona maiores possibilidades para que os jovens das famílias rurais possam estudar, geralmente, nas cidades, pois o campo tem acesso até o Ensino Médio, sendo que, na maior parte, há apenas disponibilidade até o Ensino Fundamental. Para os jovens, contudo, a conciliação entre os estudos urbanos e a moradia e/ou trabalho no campo (ou vice-versa) esbarra na precariedade de infraestrutura, tornando-se um impeditivo importante. Assim, a decisão de 'optar' pelo local de vida não se configura como um direito, mas sim, em um ato compulsório.

Apesar das dificuldades que as jovens destacaram para permanecer no campo, quatro jovens mulheres manifestaram a vontade de conseguir um trabalho na área formação próximo a unidade produtiva, para poderem residir com os familiares.

Para Carneiro (1999), apesar da intenção declarada de algumas jovens de residirem na localidade de origem, são poucos os que retornam após a conclusão do curso de graduação. Quando perguntamos se pretendiam permanecer no campo após o término do curso de graduação, quatro jovens pesquisadas declararam a vontade de permanecer e de retornar para a unidade produtiva familiar. Alguns trechos de cinco depoimentos das jovens rurais:

Minha intenção é permanecer no espaço rural, poder potencializar Márcio Freitas Eduardo, Daiane Carla Bordulis, Merce Paula Muller 
Eu não penso em mudar, nunca tive essa intenção de mudar, parece que a gente cria raízes (JOVEM H, 2015).

Sim, eu ainda pretendo (JOVEM G, 2015).

Como os pais são do interior, sempre moraram lá e estão sozinhos lá, então eu tenho a ideia de voltar (JOVEM F, 2015).

Pretendo permanecer (JOVEM E, 2015).

Concomitantemente à vontade de permanecer, as jovens reiteram que é preciso mudanças para que se consiga viver adequadamente no espaço rural. Em termos gerais, as mudanças citadas se referem 1) a melhoria de infraestrutura e estradas de acesso às unidades produtivas familiares; 2) a gestão da propriedade; 3) aos conflitos de geração; 4) a dificuldade em aceitar novas maneiras de aprimorar as atividades agrícolas; e 5) aos incentivos dos governos, principalmente em políticas de preços dos produtos:

Assim, como eu falei, até o pai e a mãe incentivam bastante para que a gente ficar, mas com mudanças, que nem eu falei. Por exemplo, lá em casa a gente trabalha com suinocultura, erva mate e tal. Como eu vou me formar médica veterinária, eu voltaria se o pai deixasse eu comandar lá, e, se a gente ampliasse a granja, porque assim não tem como voltar com o que só tem lá, entende? Tipo, eu voltaria se desse pra amplia lá e tem como ampliar, entende? Se fosse assim eu voltaria, senão não voltaria. Precisaria de incentivo tanto da família, como do governo também, porque não adianta, eu acho, que voltar, se continuar assim o preço como que tá, ter mercado pra vender, porque se não tem mercado, tu vai produzir se não tem mercado? Então, ter incentivo, ter com quem trabalhar, ter uma indústria boa que pague bem, assim (JOVEM D, 2015).

Os fatores apontados pela Jovem D mostram sua preocupação com o fato da atividade agropecuária ter baixo rendimento e das dificuldades de obter renda para o sustento da família, assim como da falta de incentivo do governo e a situação do mercado, constituindo fatores que desestimulam aos jovens a viver da agricultura. Além das situações de vulnerabilidade que perpassam as atividades agrícolas, a jovem coloca em questão a gestão da unidade produtiva familiar passando o comando de pai pra filha, possibilitando tensões que envolvem a gestão da unidade produtiva, pois como destacam Aguiar e Stropasolas (2010, p. 172), “[...] os projetos da família são coletivos, com pouco espaço para que o jovem invista num projeto individual na propriedade do pai". Ademais, os conflitos de geração entre os membros da família também são marcados pela desigualdade de gênero. Via de regra, na sociedade patriarcal a direção das unidades produtivas são atividades destinadas aos homens. É neste sentido que, no caso da jovem rural, muitas vezes, a 
Matriculadas na UFFS (Campi Realeza - PR e Erechim - RS)

perspectiva de assumir a gestão da unidade produtiva familiar após a conclusão do curso de graduação depende da permissão da figura masculina, representada pelo pai e/ou marido e/ou irmão/cunhado, etc:

O que acho que precisa principalmente é diálogo. Assim, é uma coisa que é bem dificil de acontecer entre pais e filhos. É dificil de você por as tuas ideias, pra fazer funcionar as coisas, que muitas vezes o pai não aceita. E mesmo no final de semana, você vai pra casa e tenta fazer alguma coisa, então que mais falta, assim, é diálogo. Assim, você se acerta pra você poder fazer as coisas. Não só aceitar, e fazer como era as coisas antes (JOVEM F, 2015).

Em depoimento, como o anteriormente citado, as jovens registraram a falta de diálogo entre pais e filhos. No caso da jovem rural cujo depoimento foi expresso anteriormente, dos pais aceitarem as inovações propostas e de desenvolver seu próprio projeto dentro da unidade produtiva familiar. Nesse sentido, Aguiar e Stropasolas (2010, p. 171-172) corroboram essas colocações ao mencionarem que na agricultura familiar predomina o "[...] modelo de gestão da propriedade centralizada na figura do pai, chefe de família, que centraliza também as decisões; na dificuldade dos pais em dialogar e aceitar ideias e inovações propostas pelos filhos (as) [...]":

Não é fácil sair de casa, você ficar cinco anos fora, e voltar $e$ provavelmente não será mais a mesma coisa, de quando eu morava lá, então provavelmente eu vou voltar com ideias novas, e eles vão estar com as mesmas ideias ou com poucas mudanças, então eu espero que dê certo esta interação de modernidade com sistema mais antigo (JOVEM G, 2015)

[...] eu continuo naquela com mudanças, porque eu acho que falta muito incentivo para pessoas. É cobrado muito de quem mora no campo, por exemplo, nós trabalhamos com leite e plantamos um pouquinho. Então porque tem que vacinar as vacas todo ano, tem que comprova vacinação, de tudo quanta coisa, é brucelose, é aftosa, tu tem que comprovar, isso tudo gera gasto, mas a gente não tem um incentivo pra melhorar a propriedade assim, porque fora isso ali tem muita cobrança, aí do leite mesmo, a instrução normativa 51 e outras cobranças. [...] Mais valorização mesmo do produto, estrada, que as estradas estão sempre ruim, a gente não tem locomoção, a maioria vai embora, não tem estrada boa, daí é dificil o acesso, daí se tiver uma estrada boa ajuda muito (JOVEM H, 2015).

[...] eu gostaria de permanecer trabalhando lá, só que as condições de trabalho e a valorização da agricultura ultimamente tá difícil, a questão do preço das mercadorias, essas questões. Eu acho que precisa de mais conhecimento, mais valorização, porque como eu citei antes a questão da desvalorização de produtos, de preços, o que o agricultor tem mais pra vender, lá que a gente tira o nosso sustento

Márcio Freitas Eduardo, Daiane Carla Bordulis, Merce Paula Muller 
e aí o que sobra a gente comercializa, mas o preço é pequeno né? (JOVEM E, 2015).

No que as jovens rurais relataram como necessário para permanência no espaço rural, alguns elementos estruturais foram destacados como 1) dificuldades da vida no campo; e 2) as condições precárias de infraestrutura encontradas no meio rural, revelado pelas más condições das estradas que dificultam a continuidade dos estudos, para o transporte da produção e mesmo para deslocamentos cotidianos. Nesse mesmo sentido, 3) o preço dos produtos; $\mathrm{e}, 4)$ os incentivos para melhorias na unidade de produção, foram considerados importantes para permanência no espaço rural. Como podemos verificar no depoimento a seguir, as inúmeras exigências no processo de produção, como na produção de leite, materializam as dificuldades para a permanência no campo com maior qualidade de vida:

Ah, mais lazer, eu acho, por isso acho que os jovens têm saído do campo, acho, na cidade eles têm mais opção de fazer as coisas, quando a gente vai pra casa a gente fica em casa, não tem outra coisa pra fazer, podia ter um investimento ou mais programas para incentivar os jovens a ficar, tendo mais lazer, eu acho (JOVEM C, 2015).

Outro aspecto que recai sobre as jovens rurais para permanência são as poucas opções de lazer ou a própria ausência nas comunidades rurais. Além do depoimento da Jovem C, outras jovens destacaram em suas entrevistas a falta de opções de lazer no espaço rural. Segundo Aguiar e Stropasolas (2010, p. 164), "são as moças quem mais se ressentem da falta de lazer no meio rural". Segundo os autores, os jovens homens são os que têm mais acesso a formas variadas de lazer e mais autonomia para sair.

Para as jovens rurais que colocam como projeto de vida a permanência, fazem questão de apresentar o desejo de mudanças, não querendo reproduzir o que os pais fazem, querendo implantar novas formas de trabalhar na unidade produtiva familiar. Não sendo possível a mudança, desejam trabalhar na profissão fora do estabelecimento. Outras almejam melhorias de infraestrutura, mais investimentos, preços justos e espaços de lazer para a consequente permanência no espaço rural.

\section{Desterritorialização das Jovens Rurais: Fatores Repulsivos Rurais e Atrativos Urbanos em Erechim/RS}

$\mathrm{Na}$ agricultura familiar, como vimos, as mulheres e, especialmente as jovens, encontram-se inseridas em distintos sistemas de opressão, internos e externos à unidade de produção. $\mathrm{O}$ intenso fenômeno do êxodo rural, presente na área de abrangência da Universidade Federal da Fronteira Sul, e, mais especificamente na microrregião de Erechim, é revelador da aguda crise da agricultura familiar, incluindo os problemas atrelados às questões de juventude e de gênero.

Conforme estudo de Gaboardi e Eduardo (2015), fica evidente que a desterritorialização da população rural continua latente nas duas últimas 
décadas, notadamente entre os jovens. Segundo os Censos Demográficos do IBGE, entre 1991 e 2010, Erechim foi o único município de sua microrregião geográfica a ter acréscimo (em aproximadamente $27 \%$ ) de sua população jovem total. Os demais 29 municípios da microrregião de Erechim perderam população jovem entre 15 e 29 anos. Dos 21 municípios com dados entre os períodos dos Censos Demográficos do IBGE de 1991 e 2010, 14 perderam sua população jovem total em mais de $30 \%$. Alguns municípios como Áurea, Aratiba, Campinas do Sul, Itatiba do Sul, São Valentim e Viadutos, tiveram redução em mais de $50 \%$ de sua população jovem total nas duas últimas décadas.

Gráfico 01: Variação da População Rural entre 15 e 29 anos na Microrregião de Erechim.

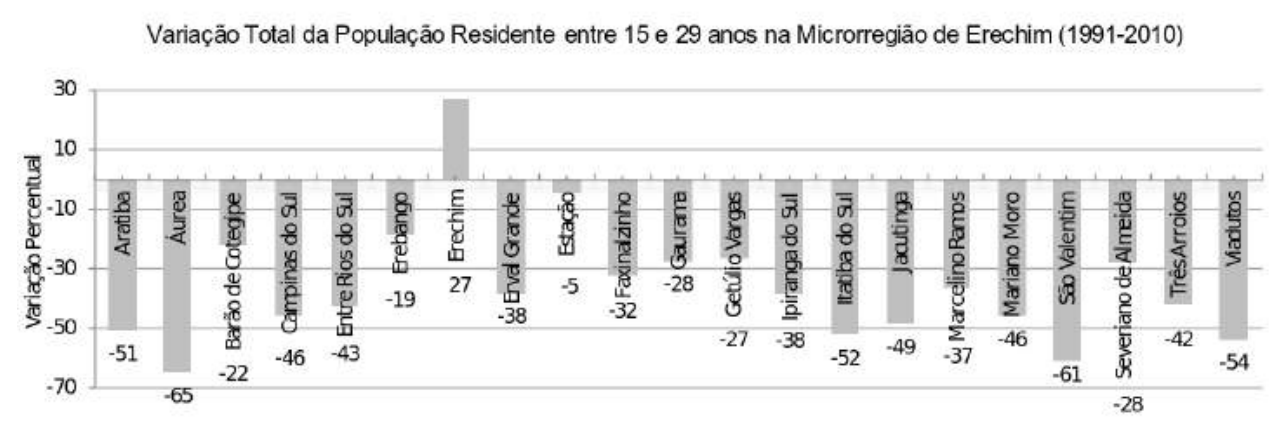

Fonte: (IBGE, 1991 e 2010). Org.: Gaboardi e Eduardo (2015). Obs.: Os municípios faltantes não apresentaram informações.

A população jovem rural, por seu turno, é a que mais tem se evadido nos distintos municípios da microrregião de Erechim (gráfico 01): em média 62\% nos 21 municípios com dados disponíveis entre 1991 e 2010. Em Aratiba, Áurea, Campinas do Sul, Entre Rios do Sul, Getúlio Vargas, Jacutinga, São Valentim e Viadutos houve reduções ainda mais significativas, com mais de $70 \%$ de evasão dos jovens rurais.

Se considerarmos, nos dados do Censo Demográfico do IBGE (1991 e 2010), a divisão juvenil por sexo, no que tange a população masculina, de 13.671 jovens entre 15 a 29 anos residentes no meio rural ano de 1991, houve redução para 6.151 no ano de 2010. Já a população feminina referente a essa mesma faixa etária, de 11.799 jovens mulheres residentes no espaço rural no ano de 1991, reduziu para 5.302 no ano de 2010. Os dados são expressivos, pois retratam uma redução de mais de $50 \%$ de população jovem, tanto masculina como feminina, no período.

Identificamos e entrevistamos 21 discentes, licenciandas nos cursos noturnos da UFFS, campus Erechim, que se enquadraram no perfil pretendido, a saber, todas jovens que migraram do campo para a cidade. Duas entrevistadas, atualmente, tinham mais de trinta anos (34 e 39 anos), porém, evadiram-se do campo no período em que eram jovens, portanto, estão contempladas em nossa pesquisa. A média da idade das entrevistadas ficou em 23 anos. Os cursos em que se encontravam matriculadas na instituição eram: Geografia (07), História (05), Pedagogia (06), Ciências Sociais (02) e Filosofia (01). De 20 respostas obtidas, 16 informaram terem residido no espaço rural de municípios da microrregião de Erechim. 
Matriculadas na UFFS (Campi Realeza - PR e Erechim - RS)

Com relação à estrutura demográfica das famílias antes e após as jovens terem migrado dos estabelecimentos agropecuários, a média de pessoas por família era de 4 e, ao longo do processo migratório que atingiram as jovens (e outros parentes), a média de pessoas por família diminuiu para 1.95, ou seja, a média é menos que duas pessoas por família, então, tem casos que nem o casal mora mais no campo, representando uma redução de, aproximadamente, 50\% do contingente populacional em âmbito das famílias estudadas. A sucessão na agricultura familiar por parte desse universo está claramente comprometida. Atualmente, restam 4 jovens mulheres e 4 jovens homens em âmbito das 21 famílias das jovens estudadas. Igualmente, a redução do contingente de familiares 'pais' nos estabelecimentos foi de 34\%.

Com relação ao tamanho dos estabelecimentos agropecuários, 21 entrevistadas precisaram as informações: $43 \%$ dos estabelecimentos possuíam até 10 hectares. Desses, $28 \%$ possuíam até 5 hectares. $\mathrm{O}$ menor estabelecimento e o maior, respectivamente, continham 2 e 60 hectares. As menores áreas têm uma participação importante do total dos estabelecimentos. Todos, porém, enquadram-se como estabelecimentos de agricultura familiar, conforme lei $\mathrm{n}^{\mathrm{o}} 11.326$, de 24 de julho de 2006.

Em sua maioria, as jovens saíram do campo em idades que variaram entre 1 e 19 anos e a média de idade em que migraram do campo ficou em 14,5 anos. Mas, se tirarmos as jovens que ficaram destoantes das outras médias com idades de 1, 4 e 5 anos, o valor da média de idade aumentaria para 16, 4 anos. Se considerarmos a média de idade em que as jovens migraram, a escolarização no ensino básico é um fator que influi na permanência relativa das jovens nos estabelecimentos. Além de estudar, 22,2\% das jovens assinalaram cozinhar no estabelecimento em que residiam e $30 \%$ das jovens mencionaram auxiliar suas famílias nos afazeres domésticos: estes dois últimos aspectos sinalizam para a divisão sexual do trabalho, algo recorrente nos estabelecimentos de agricultura familiar.

As jovens pesquisadas, conforme representado no gráfico 02 , assinalaram,

Gráfico 02: Outras atividades desenvolvidas pelas entrevistadas na época em que residiam no estabelecimento agropecuário (percentual).
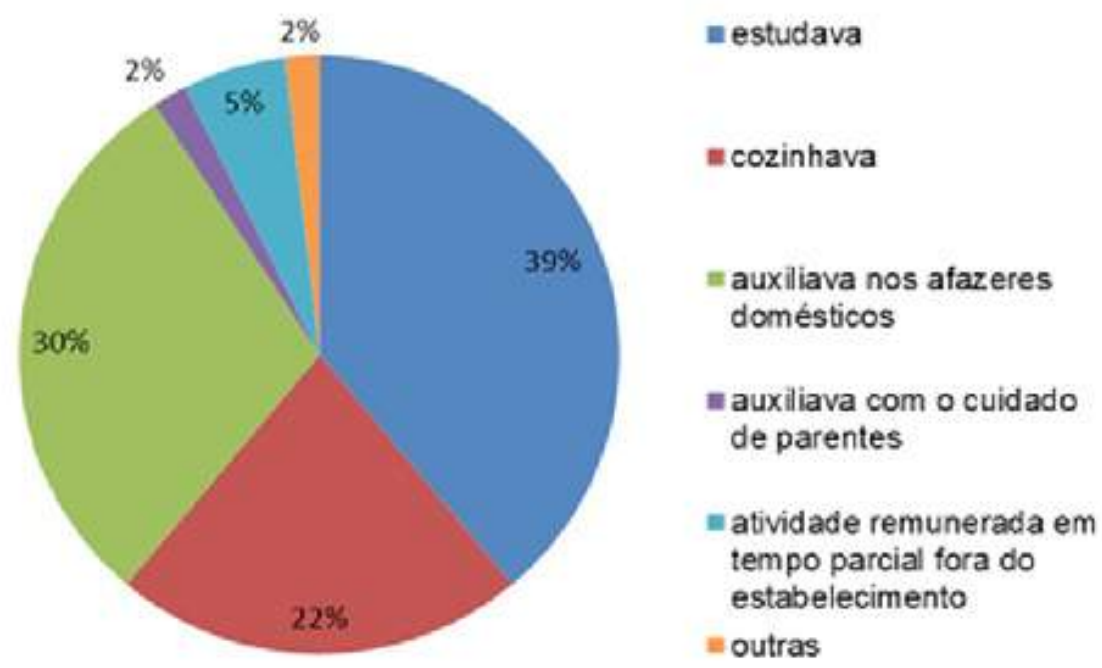

Fonte: Bordulis, 2017.

Márcio Freitas Eduardo, Daiane Carla Bordulis, Merce Paula Muller 
em razão de importância, que estudavam, auxiliavam nos afazeres domésticos e cozinhavam quando ainda residiam no espaço rural, pois eram tarefas executadas geralmente pelas mulheres, mães e filhas. Como destaca Brumer (2004, p. 211-212), “[...] as mulheres, ainda, responsabilizam-se praticamente sozinhas pelo trabalho doméstico, no qual com frequência são auxiliadas ou substituídas pelas mulheres filhas, quando têm outra atividade".

Quanto aos fatores repulsivos que influenciaram as entrevistadas na decisão de migrarem do campo, há indicações diversas, como constam no gráfico 03 . Em razão de importância, as dificuldades econômicas e a pouca demanda por trabalho foram as principais, seguidas da exiguidade de infraestrutura (educação, saúde, internet etc.), machismo, dificuldade de acesso ao crédito, pouca área de terra, escassez de opções de lazer e trabalho pesado.

Se avaliarmos as informações dos gráficos 03 e 04 , isso nos leva a crer que, embora sejam importantes os fatores repulsivos, são os fatores atrativos da cidade que impactam, de fato, a decisão das jovens de migrar. Essa nossa hipótese é corroborada por outro dado: interrogadas a respeito se voltariam a morar no campo e a trabalhar em atividades agropecuárias, 35\% das entrevistadas sinalizaram positivamente, $40 \%$ assinalaram negativamente e $25 \%$ responderam que não sabiam no momento. Se, por um lado, é contundente a saída dos jovens, há ainda expectativa de volta por parte destes, caso haja condições concretas para a reterritorialização nos espaços rurais.

Em relação à saída das jovens do meio rural, Abramovay et al $(1998$, p. 75$)$ afirma:

[...] o processo de saída das moças do campo faz parte de um declínio do próprio caráter patriarcal que caracteriza tradicionalmente a família camponesa. O enfraquecimento destas obrigações tradicionais não é acompanhado por mudança no papel das moças no interior da família.

No caso das jovens pesquisadas, a saída do campo relaciona-se com a busca pela formação profissional em nível superior, na busca pela construção de um projeto de vida que represente um avanço em relação à territorialidade passiva expressa pelo predomínio do patriarcado e do adultocentrismo na agricultura familiar.

Quanto aos fatores atrativos urbanos, em Erechim, RS, mais especificamente, há um número considerável de respostas para vários campos. $\mathrm{O}$ acesso à Universidade, a maior oferta de emprego e a obtenção de salário foram preponderantes, seguidos dos campos evolução pessoal, proximidade do comércio e dos serviços, maior quantidade de infraestrutura, da diversidade de opções de lazer, acesso a informação e do trabalho mais leve. Em função das respostas, a expectativa de uma ascensão profissional pelo acesso à educação superior e as possibilidades econômicas que a cidade oferece (com tipos mais leves de trabalho em relação ao campo e que geram um salário) para a permanência dessas jovens na Universidade são fatores cruciais pela escolha de residirem em Erechim. Posteriormente, a evolução pessoal, infraestrutura disponível (Internet, comércio e serviços, etc.) e a proximidade dos serviços pesaram nas decisões. Dessa forma, os fatores atrativos são, em grande 
Juventude, Agricultura Familiar e Gênero: Um Olhar a Partir das Estudantes

Matriculadas na UFFS (Campi Realeza - PR e Erechim - RS)

medida, econômicos também, pois a busca pela inclusão econômica, trabalho, é uma estratégia fundamental para as jovens ativarem suas territorialidades e superarem alguns dos problemas de gênero vivenciados no campo.

Gráfico 03: Fatores repulsivos existentes no campo responsáveis pelas jovens migrarem para a cidade.
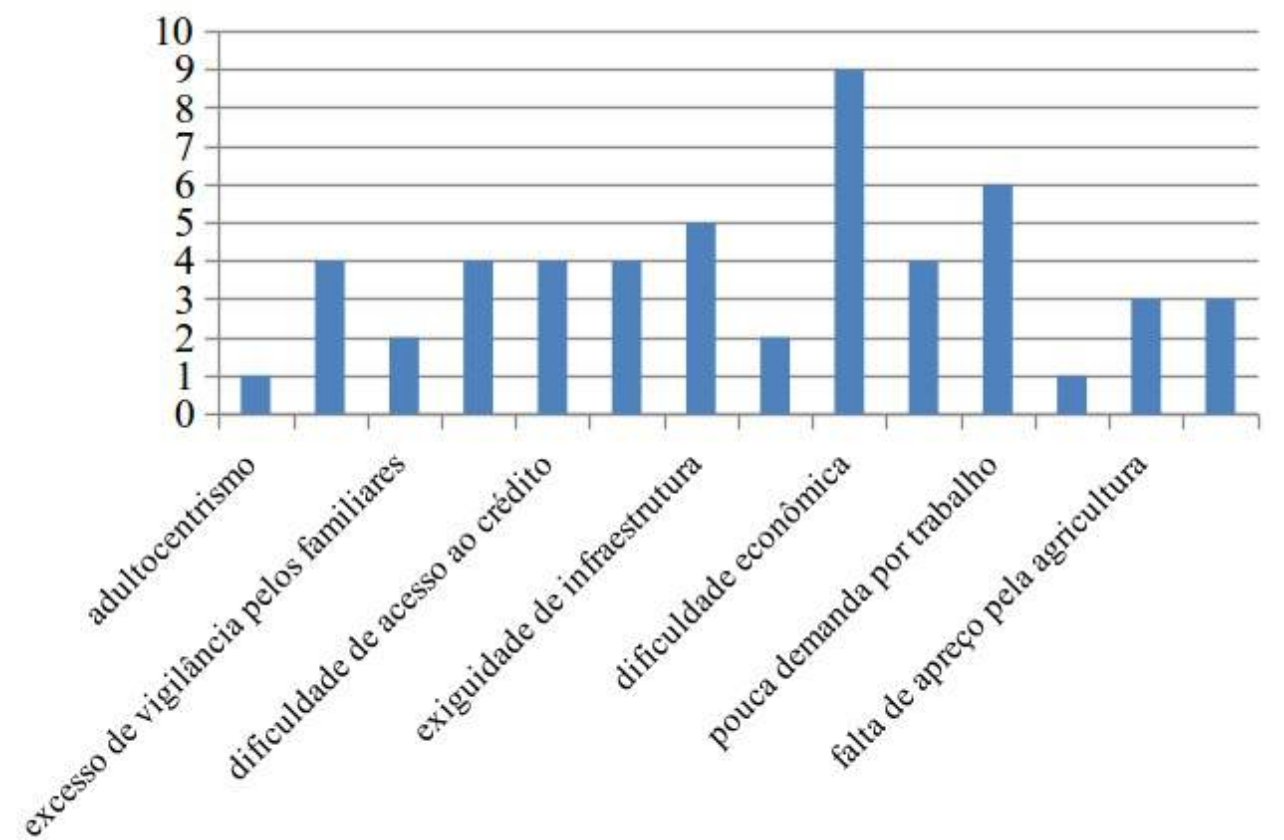

Fonte: Bordulis, 2017.

Gráfico 04: Fatores atrativos existentes na cidade responsáveis pelas jovens migrarem.

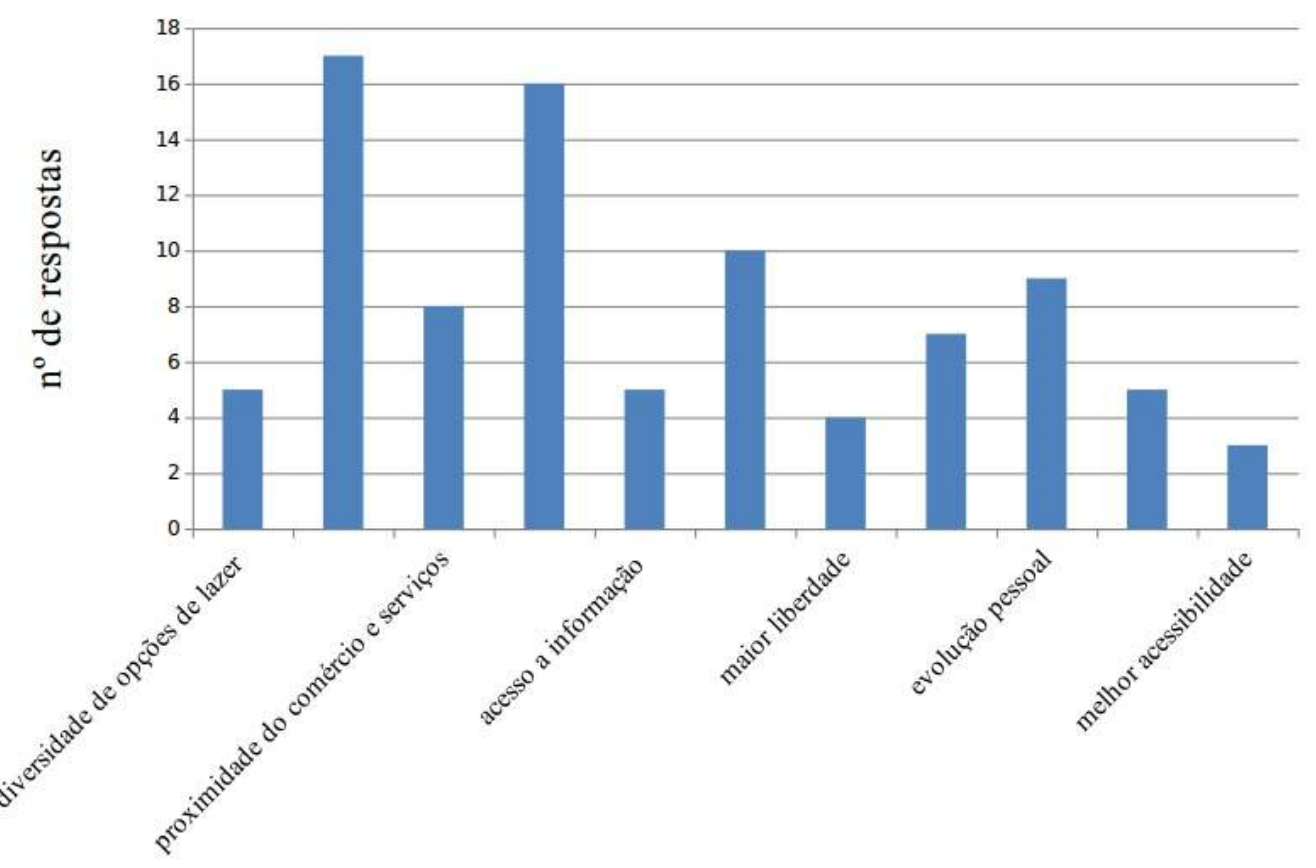

Fonte: Bordulis, 2017.

Márcio Freitas Eduardo, Daiane Carla Bordulis, Merce Paula Muller 
Matriculadas na UFFS (Campi Realeza - PR e Erechim - RS)

Ainda assim, o apoio da família para residirem na cidade é considerado importante para $84 \%$ das entrevistadas. Mais especificamente, 18,5\% afirmaram ser importante o apoio financeiro, 52\% a doação de alimentos, 33\% a prática do incentivo psicológico e 5\% responderam outras formas de apoio. Nesse campo, as jovens poderiam assinalar uma ou mais opções. Com a migração das jovens as relações com o campo continuam, não havendo um rompimento definitivo na territorialidade rural.

Em nossa pesquisa contemplamos, também, perguntas para identificarmos uma possível questão de gênero presente nas dimensões do trabalho e da participação política das jovens no âmbito de suas famílias.

Conforme consta no gráfico 05 , para $57 \%$ das entrevistadas, a divisão do trabalho entre homens e mulheres era parcialmente dividida, para $28,5 \%$ altamente dividida e 14,2\% das entrevistadas consideraram não haver divisões. Em síntese, aproximadamente $86 \%$ das respostas sinalizaram ser parcialmente ou altamente divido o trabalho entre homens e mulheres, corroborando com nossa hipótese inicial, a de que há, efetivamente, papéis produtivos com certo grau de distinção entre os sexos, implicando numa questão de gênero dentro dos estabelecimentos familiares, pois, como afirma Battestin (2009, p. 68), uma forma de divisão do trabalho dentro da agricultura familiar:

[...] se organiza através do trabalho conjunto dos membros da família, e as mulheres (mães e filhas) desempenham papel preponderante, através de atividades que exercem, seja nos âmbitos chamados domésticos, produtivo ou comunitário. Entretanto, essas atividades são comumente caracterizadas como uma obrigação natural ou tomadas apenas como uma ajuda, de caráter complementar ao trabalho do homem.

Gráfico 05: Divisão interna do trabalho pela família entre homens e mulheres dentro do estabelecimento agropecuário (percentual).
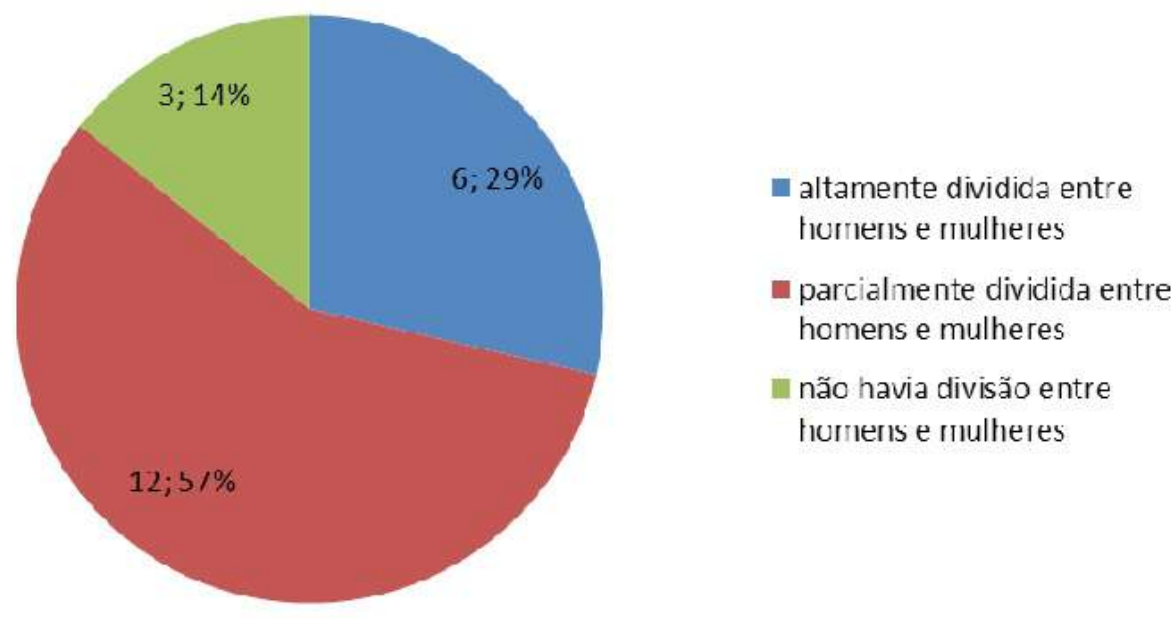

Fonte: Bordulis, 2017. 
A partir do apontamento do autor, percebemos, ainda, forte a avaliação do trabalho da mulher na unidade produtiva, sendo considerado com uma "ajuda" no desenvolvimento das atividades, um trabalho considerado subalterno e com pouco reconhecimento em relação ao trabalho masculino, dessa forma $o$ patriarcado está presente nas relações familiares.

Com relação ao grau de participação das jovens, em face da participação dos homens nas decisões e mudanças implementadas nos estabelecimentos agropecuários (gráfico 06), a maioria das respostas considerou a participação das jovens "regular" e outras não participavam. O campo de participação "boa" foi identificado com $14 \%$ para as jovens e, para os homens, $47 \%$. Tratase de outro indicador a respeito das implicações das relações de gênero e do adultocentrismo quanto a baixa participação política das jovens nos estabelecimentos agropecuários. Além disso, outra diferença significativa, demonstrada no gráfico 06 , foi o campo "excelente", onde apenas $5 \%$ das jovens revelaram ter esse grau de participação dentro da unidade produtiva familiar, enquanto os homens tiveram 38\%.

Gráfico 06: Grau de participação das jovens e dos homens nas decisões produtivas que eram implementadas pelas famílias no estabelecimento agropecuário.

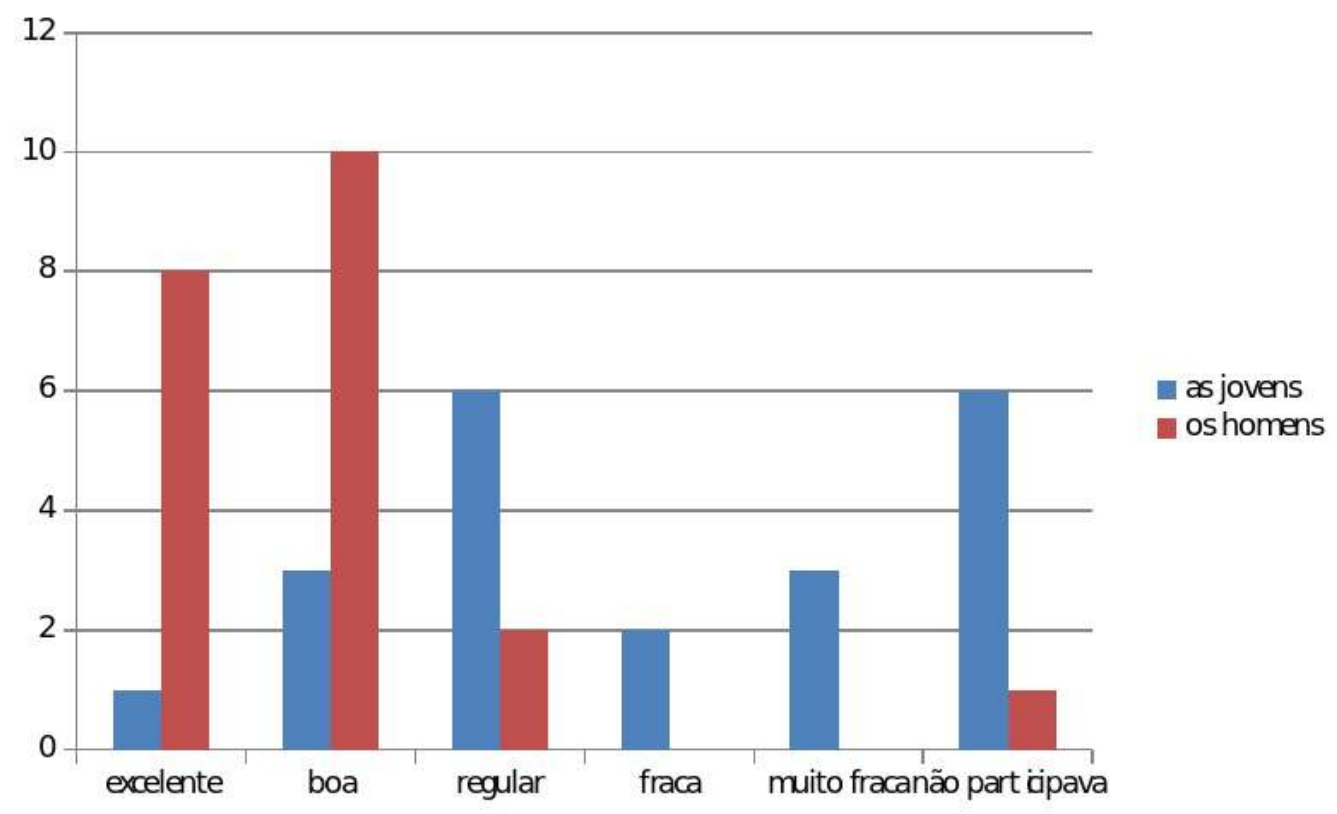

Fonte: Bordulis, 2017.

Consoante aos retornos obtidos com a aplicação dos questionários, 17 jovens afirmaram possuírem atividades geradoras de renda no meio urbano e 1 assinalou não possuir. Os vínculos empregatícios formais, elencados pelas jovens, foram: comércio (trabalho em loja, vendas, materiais de construção, secretária, empregada doméstica, jornalista e balconista), serviços (auxiliar na educação infantil, estagiária na prefeitura municipal de Erechim) e outras 2 jovens possuem bolsas de pesquisas ou de extensão na UFFS. Completando nossas questões sobre o acesso à renda em dinheiro, 2 jovens responderam receber o auxílio socioeconômico da UFFS.

Evidenciamos, através desta pesquisa com as estudantes dos cursos de 
licenciatura noturno da UFFS, campus Erechim, que a questão de gênero não responde isoladamente e nem é o principal fator repulsivo do contexto de migração das jovens rurais no campo. O principal fator repulsivo elencado são as dificuldades econômicas em que as jovens e suas famílias viviam, pois, em pouca área de terra, a família produzia em grande medida grãos, em áreas parcialmente mecanizáveis e, ainda, dependiam de maquinários alugados para realizar as práticas produtivas. Nessas condições mencionadas acima, a produção convencional de grãos se torna inapropriada.

Mesmo consistindo em um fenômeno multifatorial, a dimensão econômica possui peso importante na migração das jovens. Poderíamos supor (ao passo que estimulamos pesquisas nessa direção) que se houvesse viabilidade econômica nos estabelecimentos agropecuários, as jovens tenderiam a permanecer no meio rural, mesmo sopesando as questões de gênero. No entanto, políticas públicas de fomento à permanência das jovens no campo devem contemplar o tema do gênero em sua relação com a multidimensionalidade da vida (econômica, política, cultural e ambiental).

\section{Considerações Finais}

Na Geografia brasileira, os estudos sobre as questões de gênero são recentes e pouco expressivos numericamente. Nesse rol, as pesquisas sobre a juventude rural nos contextos socioespaciais da agricultura familiar são ainda mais escassos. Embora relevantes, os problemas enfrentados pela agricultura familiar na Mesorregião da Grande Fronteira do MERCOSUL não se resumem à dimensão econômica e a faceta técnica-produtiva. A compreensão das contradições inerentes à condição de existência do jovem e da jovem no campo é, também, aspecto importante a considerar para a adoção de ações de fortalecimento da agricultura familiar. Nesse sentido, faz-se premente um olhar atento para os fenômenos de ordem cultural e as mediações políticas (no sentido amplo do termo) que ensejam o status quo das relações sociais na agricultura familiar.

Como conferimos nas pesquisas apresentadas, a intensa evasão dos jovens dos espaços rurais da 'Fronteira Sul' acirra o problema referente à sucessão na agricultura familiar. Caso esse quadro persista, qual forma de agricultura, baseada em quais relações sociais e ecológicas, projetar-se-á muito em breve?

Ao consideramos os fatores repulsivos atrelados à desterritorialização das jovens dos espaços da agricultura familiar, constatamos que as dificuldades de viabilização econômica dos estabelecimentos formam um importante pano de fundo onde se agregam outras contradições, são elas: o adultocentrismo e os sistemas de opressão de gênero. Tais contradições permeiam a territorialidade dos jovens (e ainda mais intensamente das jovens) nas distintas escalas da vida de relações no campo, seja na residência, nas relações estabelecidas na unidade de produção, ou mesmo na sociabilidade junto à "comunidade rural" e com o cotidiano das pequenas cidades. Os sistemas de opressão adultocêntricos e de gênero implicam na sujeição dos projetos de vida dos jovens e das mulheres, aos marcos de um conservadorismo adulto e patriarcal. Nessa esteira, as mulheres jovens veem-se subsumidas a um duplo sistema de opressão: 1) o econômico, relacionado, em grande medida, com a assimetria das relações 
Matriculadas na UFFS (Campi Realeza - PR e Erechim - RS)

forjadas entre os modos de viver e de produzir da agricultura familiar em face às intencionalidades que configuram o lugar do campo nas macroescalas do sistema econômico-social capitalista; e 2) o político-cultural: movimento pelo qual, ao que tange as desigualdades de gênero, as jovens encontram excessiva dificuldade para construírem seus projetos de vida, para ampliarem seus quadros de autonomias relativas, isto é, no dizer de Dematteis (2008), para ativarem suas territorialidades diante do status quo conservador que privilegia, especialmente, os homens e os adultos e relegam segmentos da juventude à territorialidade passiva, circunscrita por estruturas de controle pré-definidas e verticais.

Acreditamos que a evasão das jovens do campo é uma resposta à edificação de uma agricultura conservadora e hegemonicamente masculina: modelo o qual as mulheres se veem com pouca margem de ingerência. Não é fortuito, por outro lado, que modelos insurgentes de agricultura, como no caso da agroecologia, despertem o interesse das mulheres. Outrossim, na agroecologia as mulheres são apreendidas como atores do desenvolvimento. São sujeitos sociais que têm muito a contribuir com uma agricultura diversa e de base ecológica ao ativarem suas territorialidades, isto é, ao colocarem em prática seus conhecimentos e visões de mundo na estruturação de outro desenvolvimento.

Na mesma direção, sinaliza o PPI da UFFS: na premência em transpor determinadas contradições sociais e limites ecológicos do desenvolvimento regional deflagrados pelo projeto em que se assenta a matriz produtiva hegemônica na 'Fronteira Sul'. Uma faceta do campo cada vez mais restrita à dimensão da produção é territorializada cotidianamente em detrimento da diversidade e da multidimensionalidade que, historicamente, configuraram os modos de vida e de produção familiares na agricultura. As carências de infraestruturas, de serviços e de opções de lazer, conforme apontados pelas jovens enquanto fatores repulsivos rurais, são retratos de um espaço rural recrudescido sob a tutela do econômico. Em síntese, um 'espaço' para a produção imperando sobre as 'espacialidades' dos modos de vida. Não obstante, o desinteresse de muitas jovens de retornar ao campo após concluírem seus cursos superiores na UFFS espelha a diversidade de contradições em que a agricultura familiar está inserida, em sua dinâmica interna e também em sua relação com a exterioridade.

Diante desses conflitos, em seus movimentos de reterritorialização, as jovens rurais buscam, nos espaços urbanos e no ensino superior público, reconstruir seus projetos de vida com base na ampliação relativa de suas autonomias. $\mathrm{O}$ acesso relativo ao dinheiro (salários, bolsas e auxílios da UFFS) e a qualificação profissional em nível superior são opções factíveis a muitas jovens, mesmo àquelas advindas de situações marcadas pelo elevado grau de vulnerabilidade econômica. Soma-se a essas motivações, a disponibilidade relativa de infraestruturas, de serviços e de opções de lazer urbanos, anteriormente dificultadas às jovens devido as suas condições sociais e espaciais de existência.

A desterritorialização das jovens rurais, em tempos recentes, reafirma-nos como o espaço é uma dimensão ativa socialmente. Para as jovens que estudamos, a tentativa de mudar suas condições de vida implicou, 
Matriculadas na UFFS (Campi Realeza - PR e Erechim - RS)

necessariamente, em atitudes que as levaram a romper seus vínculos espaciais pretéritos. Ficar no espaço rural significaria reproduzir sua existência dentro de limites, em grande medida, preestabelecidos. Ficar no espaço rural condicionaria as jovens à falta de acesso aos recursos da mudança pessoal e profissional desejados.

\section{Referências}

ABRAMOVAY, Ricardo. et al. Juventude e agricultura familiar: desafios dos novos padrões sucessórios. Brasília: UNESCO, 1998.

AGUIAR, Vilenia Venancio Porto; STROPASOLAS, Valmir Luiz. As problemáticas de gênero e geração nas comunidades rurais de Santa Catarina. In: SCOTT, Parry; CORDEIRO, Rosineide; MENEZES, Marilda. Gênero e geração em contextos rurais. Florianópolis: Ed. Mulheres, 2010, p. 157 182.

ANDRÉ, Isabel Margarida. O gênero em geografia: introdução de um novo tema. Finisterra, v. 25, n. 50, p. 334 - 348, 1990.

BORDULIS, Daiane C.. A desterritorialização das jovens rurais: um olhar para as estudantes dos cursos de licenciatura campus/Erechim. 2017. Monografia (Trabalho de conclusão de curso) - Universidade Federal da Fronteira Sul Campus Erechim, Erechim.

BATTESTIN, Simone. Ser jovem e ser agricultor: a agricultura familiar como perspectiva e projeto de vida para filhos e filhas de agricultores do município de Anchieta ES. 2009. Dissertação (Mestrado em Extensão Rural) - Universidade Federal de Viçosa.

BRUMER, Anita; ANJOS, Gabriele dos. Gênero e reprodução social na agricultura familiar. Revista NERA, ano 11, n. 12, p. 6 - 17, 2008.

BRUMER, Anita. Gênero e Agricultura: a situação da mulher na agricultura do Rio Grande do Sul. Revista. Estudos Feministas, v. 12, p. 205 - 227, 2004.

CARNEIRO, M. J. O ideal urbano: campo e cidade no imaginário de jovens rurais. In: SANTOS, R.; CARVALHO, Luis Flávio; SILVA, F.C.T (Orgs) Mundo rural e política: ensaios interdisciplinares. Rio de Janeiro: Campus, 1999, p. $97-117$.

CASTRO, Elisa Guaraná de. Entre ficar e sair: uma etnografia da construção da categoria jovem rural. 2005. Tese (Doutorado Antropologia Social) - Universidade Federal do Rio de Janeiro, Rio de Janeiro.

DEMATTEIS, Giuseppe. Sistema Local Territorial (SLOT): um instrumento para representar, ler e transformar o território. In: ALVES, Adilson Francelino; CARRIJO, Beatriz Rodrigues; CANDIOTTO, Luciano Zanetti Pessôa [Org.]. 
Juventude, Agricultura Familiar e Gênero: Um Olhar a Partir das Estudantes

Matriculadas na UFFS (Campi Realeza - PR e Erechim - RS)

Desenvolvimento territorial e agroecologia. São Paulo: Expressão Popular, 2008, p. $33-46$.

GABOARDI, Shaiane Carla; EDUARDO, Márcio Freitas. Microrregião de Erechim/RS: agricultura familiar e as transformações recentes no espaço rural. In: VII Simpósio Internacional de Geografia Agrária e VIII Simpósio Nacional de Geografia Agrária, 2015, Goiânia, GO. Anais... Goiânia: UFG Editora, 2015.

MOREIRA, Rui. Pensar e ser em Geografia. São Paulo: Editora Contexto, 2011.

MULLER, Merce P.. As jovens rurais e as perspectivas de permanência no espaço rural: um estudo de caso no campus Realeza da Universidade Federal da Fronteira Sul. 2016. Dissertação (Mestrado em Geografia) Universidade Estadual do Oeste do Paraná, Francisco Beltrão.

OLIVEIRA, Ariovaldo Umbelino de. Agricultura camponesa no Brasil. São Paulo: Ed. Contexto, 2001.

PIRES, Lucineide Mendes. Culturas Geográficas de alunos-jovens: uma referência para a formação de professores de geografia. 2013. Tese (Doutorado em Geografia) - Universidade Federal de Goiás. Goiânia.

SANTOS, Roseli Alves dos. A Participação política das mulheres agricultoras nas organizações populares e sindicais no sudoeste do Paraná. Revista Geouerj, v. 2, n. 21, p. $1-17,2010$.

SILVA, Joseli Maria. Um ensaio sobre as potencialidades do uso do conceito de gênero na análise geográfica. Revista de História Regional, v. 8, n. 1, p. 31 - 45, 2003.

SILVA, Carolina Braz de Castilho; SCHNEIDER, Sérgio. Gênero, trabalho rural e pluriatividade. In: SCOTT, Parry; CORDEIRO, Rosineide; MENEZES, Marilda. Gênero e geração em contextos rurais. Florianópolis: Ed. Mulheres, 2010, p. $183-208$.

SCOTT, Joan. Gênero: uma categoria útil na análise histórica. Revista Educação e Realidade, v. 20 n. 2, p. 71 - 99, 1995.

UNIVERSIDADE FEDERAL DA FRONTEIRA SUL. Projeto Político Institucional (PPI). Disponível em $<$ http://uffs.edu.br/index.php?option=com_content\&view=article\&id=87\&Ite $\mathrm{m}$ id $=825>$. Acesso em 08 de abril de $201 \overline{6}$.

WAGNER, Saionara Araújo; MARQUES, Flávia Charão; MENASCHE, Renata; Agricultura familiar à mesa. In: MENASCHE, Renata (Org.). Agricultura familiar à mesa: Saberes e práticas da alimentação no Vale do 
Juventude, Agricultura Familiar e Gênero: Um Olhar a Partir das Estudantes

Matriculadas na UFFS (Campi Realeza - PR e Erechim - RS)

Taquari. Rio Grande do Sul: UERGS, 2007, p. 1 - 197.

WEISHEIMER, Nilson. Juventudes rurais: mapa de estudos recentes.

Brasília: Ministério do Desenvolvimento Agrário/NEAD, 2005. 